IRENEUSZ M. ŚWITAEA

ORCID 0000-0002-8823-7955

Uniwersytet Pedagogiczny im. Komisji Edukacji Narodowej

$w$ Krakowie

\title{
WYCHOWANIE DO WARTOŚCI W ZMIENIAJĄCYM SIĘ ŚWIECIE
}

\begin{abstract}
AвSTRAct. Świtała Ireneusz M., Wychowanie do wartości w zmieniającym się świecie [Value-Oriented Upbringing in the Changing World]. Studia Edukacyjne nr 52, 2019, Poznań 2019, pp. 159-172. Adam Mickiewicz University Press. ISSN 1233-6688. DOI: 10.14746/se.2019.52.11

The need for value-oriented upbringing is obvious and necessary, though difficult in the world full of contrasts, conflicts and plurality of worldviews. Upbringing to values is aimed at preparing children and young people to individual, conscious selection and hierarchization of values and being guided by them in all areas of their personal and professional lives. Axiological education helps to gain the ability to distinguish between good and evil, truth and falsehood, selfishness and altruism. A pedagogical approach to values has become the subject of many scientific considerations and discussions among parents and teachers. This article is a review of the relationships between value systems and upbringing.
\end{abstract}

Key words: children, teenagers, upbringing, values, moral norms, educational systems, ideology, world view

\section{Wstęp}

Ostatnie dziesięciolecia charakteryzują się występowaniem dynamicznych i różnorodnych zmian polityczno-gospodarczych oraz społeczno-kulturowych, które wywierają istotny wpływ na system wartości współczesnych Polaków i proces wychowania młodego pokolenia. Demokratyczny system polityczno-społeczny, rozwój gospodarki rynkowej, wielokulturowość, pluralizm światopoglądowy, postawy hedonistyczne i podmiotowe traktowanie dzieci - to tylko niektóre cechy współczesnego społeczeństwa. Wstąpienie Polski do Unii Europejskiej spowodowało zmiany w świadomo- 
ści Polaków i potrzebę podniesienia poziomu życia, czego dowodem stały się wyjazdy zarobkowe. Chęć bogacenia się, nawet kosztem życia rodzinnego, to zauważalne zjawisko. Obecnie charakterystyczne jest występowanie kontrastów, odmiennych zjawisk, mieszanie dobra i zła, pozytywnych i negatywnych zachowań społecznych, relatywizm moralny. Powoduje to zamęt w systemie wartości, niebezpieczeństwo mylenia prawidłowych i negatywnych zasad oraz norm moralnych - czyli chaos aksjologiczny. Współcześnie obserwujemy, że w wielu dziedzinach życia rodzinnego, społecznego, gospodarczego i politycznego dochodzi do łamania podstawowych norm etycznych i pojawiania się zjawisk świadczących o braku moralności, na przykład brak poszanowania innych ludzi, brak życzliwości, fałsz, egoizm, korupcja, nepotyzm i wiele innych. Człowiek poznaje podstawowe wzorce zachowań, reguły postępowania oraz normy etyczne od chwili narodzin - uczy się ich przestrzegać i dokonywać wyborów. Ludzie żyjący na początku XXI wieku często lekceważą i łamią ogólnie przyjęte normy, nie odczuwają potrzeby ich przestrzegania, czują się wolnymi i niezależnymi jednostkami, uznając, że to sprawa osobista każdego człowieka. Moralność jest zróżnicowana, ulega historycznym przemianom; w różnych epokach odmiennie pojmowano takie wartości, jak godność, tolerancja, sprawiedliwość, wolność, czy prawa człowieka.

O złożoności i pluralizmie przekonań, jak też zachowań moralnych decydują założenia filozoficzne i światopoglądowe, warunki materialno-cywilizacyjne oraz wychowanie - które jest przekazywaniem określonych wartości. Podłożem moralności są religie lub poglądy świeckie - laickie.

Moralność religijna odwołuje się do boskich źródeł i sankcji, a laicka do źródeł uzasadnień i doczesnych sankcji społecznych. Pomimo zróżnicowania aksjologicznego występują wartości ponadczasowe, uniwersalne, ogólnoludzkie, na przykład życie, rodzina, pokój, wolność - przy występowaniu różnic $w$ innych kwestiach moralnych. To zróżnicowanie moralno-światopoglądowe wywiera niewątpliwy wpływ na proces wychowania młodych ludzi.

Głównym przekaźnikiem wartości jest wychowanie - zarówno celowe, świadome, intencjonalne, jak i naturalne, odbywające się $\mathrm{w}$ rodzinie. Wychowanie polega na celowym oddziaływaniu ludzi dorosłych (wychowawców, nauczycieli) na dzieci i młodzież (wychowanków), w celu ukształtowania w nich określonych pojęć, postaw, dążeń i wartości w warunkach konkretnej rzeczywistości społeczno-cywilizacyjnej. Działanie wychowawcze zawiera w sobie opiekę, wychowanie umysłowe, fizyczne, estetyczne i moralno-społeczne oraz działania przygotowujące młodych ludzi do życia zawodowego i rodzinnego. Działalność wychowawcza jest społecznie popierana, aprobowana, zorganizowana i odbywa się w ramach życia okre- 
ślonych grup społecznych, które stają się instytucjami wychowującymi, jak na przykład szkoła, rodzina, organizacja młodzieżowa, zajęcia pozalekcyjne i pozaszkolne ${ }^{1}$.

Obok wychowania intencjonalnego istnieje system wychowania równoległego, czyli oddziaływania mass mediów, literatury, sztuki, instytucji naukowych, kulturalnych, czy sportowych oraz wysiłki człowieka nad kształtowaniem własnej osobowości (samowychowanie).

Proces wychowania nie ogranicza się tylko do okresu dzieciństwa i młodości, lecz trwa przez całe życie, gdyż zmienia się rzeczywistość, co wymaga ciągłego doskonalenia indywidualnego (wychowanie permanentne).

Jednym z celów wychowania jest stworzenie systemu wartości, który stanowi fundament życia człowieka - ten system buduje osobowość i kształtuje życie człowieka, decyduje, co dla jednostki jest istotne, cenne, co dobre a co złe. Wpływa na nasze potrzeby dążenia, pragnienia.

Żyjemy w czasach, gdzie wartości ulegają zmianom, niektóre z nich są ciągle ważne, inne uległy przedawnieniu². Jakie wartości przekazywać dzieciom, jakie wartości promuje współczesna szkoła, czy są one zgodne z wartościami przekazywanymi w rodzinie, czy dzieci i młodzież przyjmują te wartości, czy je zinternalizują? Są to podstawowe pytania aksjologii pedagogicznej. Temat ten jest niezwykle ważny i aktualny z punktu widzenia pedagogicznego, społecznego oraz jednostkowego, ponieważ dotyczy istoty wychowania, którego ważnym celem jest przekazywanie wartości, które są elementem naszej kultury.

\section{Miejsce wartości w procesie wychowania}

Wartości stanowią fundament procesu wychowania i podstawę każdego systemu, programu, czy pojedynczego działania wychowawczego. Są czymś niezwykle cennym dla człowieka, będąc zasadniczym elementem potrzeb, mają charakter obiektywny i uniwersalny.

Wartością jest to co ważne, warte wysiłku, trwałe przekonanie, że dany sposób postępowania lub cel życiowy jest jednostkowo i społecznie bardziej atrakcyjny niż inne sposoby zachowań i cele życiowe. Wartości to normy i zasady postępowania, które umożliwiają rozwój człowieka oraz osiągnięcie satysfakcji życiowej.

Wartości wzmacniają naszą odporność na niepowodzenia życiowe, są podstawą naszych myśli, postaw, zachowań - składają się na spójny system,

${ }^{1}$ S. Kunowski, Podstawy wspótczesnej pedagogiki, Warszawa 2004, s. 19-21.

2 A. Cybal-Michalska, Zjawisko globalizacji wspótczesnego świata z perspektywy młodzieży szkót średnich, Studia Edukacyjne, 2008, 7, s. 99.

${ }^{3}$ M. Dziewiecki, Wychowanie ku wartościom, Wychowawca, 1998, 9. 
który pozwala przetrwać człowiekowi i osiągnąć szczęście w życiu osobistym czy zawodowym. Przyjęte przez człowieka wartości określają jego styl życia, stosunek do innych ludzi, pobudzają i kształtują świadomość, stymulują do działania, ukierunkowują i stabilizują rozwój ${ }^{4}$. Konkretyzacją wartości są normy moralne.

Józef Tischner twierdził, że wartości są obiektywne, działają na człowieka i go do czegoś zobowiązują ${ }^{5}$ a będąc we wzajemnych relacjach, tworzą hierarchię. Wybitny aksjolog niemiecki Max Scheler (1874-1928) wyróżnił następujące wartości:

- absolutne - jako najwyższe w hierarchii są przypisywane Bogu oraz niektórym zjawiskom przyrodniczym i społecznym, wśród nich znajdują się wartości religijne;

- duchowe - dzielą się na wartości estetyczne (piękno, wdzięk, brzydota), poznawcze (prawda, obiektywizm), w tym wartości prawne (to co jest słuszne i niesłuszne);

- witalne - to jest wartości życia, zdrowia fizycznego i psychicznego (zdrowie, choroba);

- utylitarne - określają co jest użyteczne (sprawność, wydajność, funkcjonalność);

- hedonistyczne, zmysłowe - dotyczą odczuwania stanów przyjemnych i nieprzyjemnych (ból, przyjemność, radość).

Wartości są autonomiczne, niezależne od podmiotu i przedmiotu oceny. Jako stałe i niezmienne wzorce, których nikt nie tworzy i nie jest w stanie modyfikować, stanowią rzeczowe odzwierciedlenie uczuć, są dane w uczuciach - ujawniają się w nich w sposób bezpośredni'. Będąc potrzebą oraz podmiotem dążeń ludzi, wartości realizują się poprzez aktywność i styl życia ${ }^{7}$.

Wartości są pochodną potrzeb, realizacją potrzeb - ich hierarchia odzwierciedla hierarchię potrzeb człowieka. Najbardziej znaną hierarchię potrzeb przedstawił Abraham Maslow (1908-1970), amerykański psycholog, według którego u podstaw znajdują się potrzeby fizjologiczne, powyżej potrzeba bezpieczeństwa, przynależności, miłości, szacunku i uznania, na samym szczycie piramidy mieści się potrzeba samorealizacji ${ }^{8}$.

${ }^{4}$ L. Dyczewski, Miejsce i funkcje wartości w kulturze, [w:] Kultura w kreggu wartości, red. L. Dyczewski, Lublin 2001, s. 39.

${ }^{5}$ J. Tischner, J.A. Kłoczkowski, Wobec wartości, W Drodze, 2001 s. 22.

${ }^{6}$ S. Lachowski, Droga ważniejsza niż cel. Wartości w życiu i biznesie, Warszawa 2012, s. 18 i n.; J. Lipiec, W przestrzeni wartości, Kraków 2001, s. 10.

${ }^{7}$ K. Popielski, Wartości i ich znaczenie w życiu ludzi, [w:] Człowiek - wartość - sens, red. K. Popielski, Lublin 1996, s. 59.

8 A. Maslow, Motywacja i osobowość, Warszawa 2006, s. 62. 
W literaturze przedmiotu można spotkać dwie przeciwstawne teorie wartości: obiektywistyczną i subiektywistyczną9. Pierwsza, charakterystyczna dla nurtów pedagogiki realistycznej, głosi, że wartość przedmiotu jest niezmienna i niezależna od oceny człowieka. Teoria druga - subiektywistyczna, głoszona przez zwolenników pedagogiki postmodernistycznej, zakłada, że wartości są czymś indywidualnym i relatywnym - stanowią osobistą preferencję.

Antropologiczne, społeczne, kulturowe i religijne podstawy wartości zakładają, że istnieją wśród nich takie, które obowiązują każdego człowieka, dlatego poprzez wychowanie istnieje szansa na skupienie ludzi wokół głównego ośrodka wspólnych wartości i ich utrwalenie (wartości ogólnowspólnotowe). Jednocześnie naturalnym pragnieniem każdej osoby jest poszukiwanie sensu i celu własnych działań, które są ukierunkowane na własne dobro.

Współcześnie dominują dwa nurty myślenia o wartościach:

- uniwersalistyczny, nawiązujący do antycznej triady wartości najwyższych, to jest prawdy, dobra i piękna jako podstaw wielu teorii humanistycznych w pedagogice. Proces wychowania ukierunkowany jest na realizację wartości uniwersalnych, dzięki którym stajemy się człowiekiem, to jest takich, jak: otwarcie na życie i świat, aktywność, czyli czynności człowieka ukierunkowane na pracę, wysiłek i rozwój;

- realistyczny, pozwalający na rozumienie siebie i otaczającej rzeczywistości,

oraz wrażliwość na dobro i piękno, kształtowanie uczuć i wychowanie sfery emocjonalnej - jako relacji do dóbr doczesnych ${ }^{10}$.

Inny wskazywany zespół wartości w wychowaniu to: altruizm, tolerancja, odpowiedzialność, sprawiedliwość, czy wolność ${ }^{11}$.

$\mathrm{W}$ aspekcie aksjologii pedagogicznej są:

- wartości i normy społeczne występujące poza wychowaniem;

- wartości występujące $\mathrm{w}$ wychowaniu, przyjęte nieświadomie lub świadomie $^{12}$.

Wartości w wychowaniu spełniają podwójną funkcję:

- wyznaczają cele wychowania, stanowią ich źródła i uzasadnienia;

- wyznaczają kryteria oceny działań wychowawczych ${ }^{13}$.

${ }^{9}$ J. Mariański, Między rajem a apokalipsa, [w:] O potrzebie wychowania ku wartościom uniwersalnym, red. M. Czerepaniak-Walczak, M. Dudzikowa, Warszawa 2007, s. 81.

${ }^{10} \mathrm{~K}$. Olbrycht, Wychowanie do wartości - SW centrum aksjologicznych dylematów wspótczesnej edukacji, Pedagogika Christiana, 2012, 1, s. 89-104.

${ }_{11}$ M. Łobocki, Teoria wychowania w zarysie, Kraków 2006, s. 108.

${ }_{12}$ M. Nowak, Teorie i koncepcje wychowania, Warszawa 2008, s. 367.

${ }^{13}$ M. Olbrycht, Wychowanie do wartości, s. 90. 
Współcześnie wiele nurtów pedagogicznych i powstałych na ich podstawie programów wychowawczych neguje potrzebę przekazywania wartości $\mathrm{w}$ wychowaniu, co jest przejawem pragmatyzmu ${ }^{14} \mathrm{i}$ postmodernizmu ${ }^{15}$, który zakłada odrzucenie obiektywnego aspektu wartości jako zagrożenie dla wolności człowieka.

W aksjologii pedagogicznej rozróżnia się pojęcia: „edukacja do wartości” oraz „wychowanie do wartości”. Edukacja do wartości to przekaz wiedzy o wartościach i uczenie umiejętności potrzebnych do samodzielnego wartościowania - edukacja koncentruje się na kształtowaniu pewnych kompetencji (wiedzy, umiejętności, postaw). Wychowanie do wartości jest kształtowaniem orientacji aksjologicznej, która stanowi funkcję dojrzałości, gotowości do świadomego i odpowiedzialnego wybierania wartości - dojrzałość traktowana jest jako etap rozwoju moralnego jednostki.

Obserwując współczesne trendy w wychowaniu, można zauważyć:

- rozszerzenie terenu oddziaływań wychowawczych, dotyczących nie tylko dzieci w wieku szkolnym, ale obejmujących również małe dzieci, rodziców, młodzież studiującą i pracującą, dorosłych (andragogika) i osoby starsze (gerontopedagogika), czyli że wychowanie odnosi się do całego życia ludzkiego;

- zmianę charakteru wychowania z indywidualnego na grupowe, zespołowe w różnych środowiskach (rodzina, klasa szkolna, organizacje, placówki kulturalno-oświatowe) oraz działania w skali światowej przez Organizację Narodów Zjednoczonych i UNESCO (walka z analfabetyzmem, upowszechnienie wykształcenia podstawowego i średniego);

${ }^{14}$ Pragmatyzm - system filozoficzny, którego podstawowym elementem jest pragmatyczna teoria prawdy. Uzależniając prawdziwość tez od praktycznych skutków, przyjmuje praktyczność za kryterium prawdy. Postawa polegająca na realistycznej ocenie rzeczywistości, podejmowaniu działań gwarantujących skuteczność. Teoria rozpowszechniła się w XX w., a jej twórcą był Charles Sanders Peirce $(1839$ - 1914). Synonimy pragmatyzmu: praktyczność, logiczność, rzeczowość, rozsądek.

15 Postmodernizm - ponowoczesność, podawanie w wątpliwość wszystkich systemów wartości jako arbitralnych i determinujących człowieka. Ogólnego znaczenia nabrał w latach 40. XX w.; od lat 70. XX w. używany w odniesieniu do kultury zachodniej, zniechęconej do rozumu, metod naukowych i wiary w postęp. Rozpad idei uznawanych w nowożytności za obowiązkowe. Cechy preferowane: pluralizm, dechrystianizacja życia i myślenia, relatywizm etyczny, otwartość na łączenie różnych systemów filozoficznych czy religijnych. Pedagogika postmodernizmu stanowi formę pedagogiki krytycznej. Jego przedstawiciele w pedagogice: Z. Kwieciński, L. Witkowski, T. Szkudlarek.

System oświatowy cechuje: wielobarwność nienormatywna, samoregulacja, odstąpienie od monopolu władzy państwowej bazującej na indoktrynizacji ideowej, rutyna lojalności, mechanizmy kontroli, wieloznaczność form kształcenia. Uspołecznienie i regulacje z zewnątrz zastępuje samostanowienie, samorealizacja i autoedukacja jednostki. Brak optymalnego wychowania, nie obowiązują autorytety i nie ma nacisku na posłuszeństwo i przestrzeganie norm, czy postępowanie zgodnie ze wzorami. 
- powstanie nowych instytucji opiekuńczo-wychowawczych, specjalizujących się w opiece nad dziećmi małymi (żłobki, przedszkola), opuszczonymi (domy małego dziecka, domy dziecka i inne formy opieki kompensacyjnej), nieprzystosowanymi społecznie (zakłady opiekuńczo-wychowawcze, zakłady poprawcze), jak również placówki wychowania równoległego (oświatowo-kulturalne dla dzieci i dorosłych, domy młodzieży, koła zainteresowań i organizacje sportowe czy turystyczno-krajoznawcze);

- zastosowanie nowoczesnych technik do oddziaływania masowego (mass media, nowoczesne biblioteki, Internet).

Wychowanie w obecnych czasach stało się bardzo ważne, choć nastąpiły zmiany w formach działań wychowawczych ${ }^{16}$.

Do najstarszych funkcji wychowania należały: funkcje religijne, moralne i społeczne. O celu wychowania decydują najwyższe wartości i ideały, których podstawę stanowi światopogląd zawierający zinternalizowane wartości. Jakkolwiek światopoglądy historyczne się zmieniały, zawsze dominowały w nich jakieś wartości - religijne lub świeckie.

\section{Wartość w wybranych systemach pedagogicznych w aspekcie historycznym}

Śledząc dzieje wychowania i rozwój myśli pedagogicznej, łatwo zauważyć, że w różnych epokach historycznych inaczej pojmowano ideał wychowania i wartości z nim związane.

W społecznościach pierwotnych dzieci przejmowały doświadczenia dorosłych poprzez obserwację i naśladownictwo. Z chwilą gdy człowiek zaczął wytwarzać narzędzia pracy, pojawiła się potrzeba przekazywania młodym konkretnych umiejętności. Dzieci poprzez bezpośredni udział w polowaniu i pracy gospodarczej zdobywały potrzebne im do życia sprawności - w ten sposób wrastały w społeczność pierwotną.

W drugim stadium rozwoju społeczeństwa pierwotnego poszczególne plemiona zaczęły współzawodniczyć i walczyć ze sobą, rozwijały się różnorodne wierzenia i mity plemienne, pojawiły zaczątki wychowania społecznego. Młodzieży wpajano nienawiść do wrogów i przekonanie, że zemsta jest obowiązkiem. Chłopca, który miał się stać pełnoprawnym członkiem plemienia poddawano inicjacji, czyli dokonywano wtajemniczenia i wprowadzenia w społeczność mężczyzn. Była to pierwotna instytucja wychowawcza, która miała na celu wychowanie do grupy pozarodzinnej i osłabienie więzi rodzinnych.

\footnotetext{
${ }^{16}$ S. Kunowski, Podstawy wspótczesnej pedagogiki, s. 19-21.
} 
W późniejszym okresie pojawiła się własność prywatna, niewolnictwo i rodziny monogamiczne, nastąpił podział społeczeństwa na klasy: ludzi wolnych i niewolnych, pełnoprawnych i wyzyskiwanych, co wywarło istotny wpływ na wychowanie. W tym czasie filozofowie (np. Arystoteles IV w. p.n.e.) i moraliści twierdzili, że nie wszyscy ludzie są jednakowi, a niewolnictwo jest naturalnym stanem.

Wychowanie w ustroju niewolniczym przyjmuje charakter klasowy, jego cele, treści i formy zależą od potrzeb klasy panującej.

Jak pamiętamy, w antycznej Grecji występowały dwa systemy wychowania: spartański i ateński; o różnicach między nimi decydowały sytuacja ekonomiczna, polityczna i kulturalna. Sparta była ciągłym obozem wojennym, dlatego wychowanie miało charakter surowego wychowania fizyczno-wojskowego; wybrani chłopcy od 7. do 18. roku życia wychowywali się w państwowych instytucjach (koszarach) i byli przygotowywani do służby wojskowej. Ideałami wychowania spartańskiego było ukształtowanie jednostek mocnych fizycznie, zahartowanych, zaprawionych do walki, zdyscyplinowanych, ofiarnych i odważnych. Liczyły się takie wartości, jak: siła, odwaga, zdyscyplinowanie, pogarda dla niewolników.

Wychowanie w Atenach obejmowało tylko dzieci ludzi wolnych, a wartościami przekazywanymi $\mathrm{w}$ procesie wychowania były: samodzielność, harmonijny i wszechstronny rozwój (wychowanie umysłowe, moralne, muzyczne, estetyczne i fizyczne) - zauważamy tu początki idei wykształcenia ogólnego.

Spośród filozofów starożytnych najwięcej uwagi sprawom wychowania poświęcili Platon (427-347 p.n.e.), Sokrates (469-399 p.n.e.) i Arystoteles (382322 p.n.e.).

Platon wymieniał takie wartości, jak: harmonia między ciałem a duszą, żądza, męstwo, rozum oraz cztery cnoty: umiarkowanie, odwagę, mądrość oraz sprawiedliwość. Wychowanie miało realizować idee dobra ${ }^{17}$.

Sokrates twierdził, że najważniejsze wartości, to: poznanie samego siebie (samopoznanie), samowychowanie, samodoskonalenie etyczne, samokształtowanie intelektualne i cnota jako dobro bezwzględne, które przynosi człowiekowi szczęście. Cnota jest wiedzą, a wychowanie moralne sprowadza się do wychowania intelektualnego.

Dla Arystotelesa wychowanie miało charakter polityczny i państwowy, ponieważ człowiek nie może istnieć poza społeczeństwem. Rozwijał on etykę przyjaźni, przywiązując uwagę do wszechstronnego, harmonijnego rozwoju.

17 S. Litak, Historia wychowania, t. 1, wyd. 3, Kraków 2010, s. 15-34; S. Wołoszyn, Dzieje wychowania i myśli pedagogicznej w zarysie, Warszawa 1964, s. 31-63; S. Kot, Historia wychowania, t. 1, Warszawa 1994. 
Pochwalał niewolnictwo, a wychowanie było zarezerwowane wyłącznie dla dzieci (chłopców) wolnych obywateli.

W Średniowieczu (od V do XV w.) wychowanie miało charakter stanowy (rycerskie, mieszczańskie, cechowe, duchowe), a filozoficzno-teologiczne poglądy św. Tomasza z Akwinu (1225 - 1274) stanowiły podbudowę wychowania i zostały przyjęte przez Kościół.

Wychowanie każdego dziecka determinowała jego pozycja społeczna i płeć. Człowiek średniowiecza nie mógł egzystować poza obrębem stanów feudalnych: rycerstwa, mieszczaństwa, duchowieństwa. Dzieci i młodzież wychowywano przez wprowadzenie w obowiązki danego stanu, a każdy stan miał w sobie właściwe cnoty i wartości, które wpajano młodzieży. Średniowieczne ideały skupiały się na Bogu, który jest dobrem absolutnym i przygotowaniem ludzi do życia wiecznego. Asceza i umartwianie się, rezygnacja z życiowych przyjemności, dyscyplina wewnętrzna, wyrzekanie się bogactwa, sławy, rodziny, cierpienie i ból, wiara w Boga, odwaga rycerska i honor były cenionymi wartościami.

W Renesansie (Odrodzenie XIV - XVI wiek) zaczęto interesować się człowiekiem i jego życiem doczesnym, kulturą starożytną i świeckim podejściem do wychowania oraz rozumem człowieka i naturą. Moralne jest to, co zgodne z naturą człowieka, a celem wychowania miała być mądrość, dobroć, siła, umiarkowanie, miłość i przyjaźń.

Pedagogowie - humaniści domagali się świeckiego kierunku wychowania i życzliwego traktowania dziecka (Erazm z Rotterdamu 1466 - 1536, Andrzej Frycz Modrzewski 1503 - 1572).

W Oświeceniu (koniec XVII i XVIII wiek) ideałem człowieka była osoba wolna, wykształcona, zdobywająca wiedzę przez doświadczenie, krytyczna wobec autorytetów, korzystająca z dóbr doczesnych. Preferowano wychowanie naturalne i indywidualizm. Czołowym przedstawicielem tego okresu był J.J. Rousseau (1712 - 1778), który twierdził, że "człowiek z natury jest dobry" oraz Stanisław Konarski (1700 - 1773), pragnący wychować uczciwego człowieka i rozumnego, dobrego obywatela.

Hasła rewolucji francuskiej (1789) - wolność, równość, braterstwo - wywarły niemały wpływ na wychowanie przyszłych pokoleńn ${ }^{18}$.

Romantyzm (od 90. lat XVIII do 40. XIX w.) cechowało wniesienie takich wartości, jak: walka z tyranią, bunt przeciw nierównościom społecznym, duchowość, emocjonalność, indywidualizm, dominacja uczuć nad rozumem, miłość, mistycyzm i mesjanizm ${ }^{19}$, poświęcenie się dla ojczyzny, umiłowanie

18 Tamże.

${ }_{19}$ Mistycyzm - postawa przedstawicieli epoki romantyzmu, która zakładała możliwość duchowego kontaktu z bóstwem, siłami pozaziemskimi, stawiała wyżej poznanie intuicyjne od 
wolności, rozwój wyobraźni jako mocy twórczej człowieka - które stanowiły podstawowe elementy światopoglądu w tej epoce ${ }^{20}$.

Ideał wychowawczy Komisji Edukacji Narodowej (1773 - 1794) sprowadzał się do wpojenia młodzieży takich wartości, jak: patriotyzm, rozumność, zainteresowanie sprawami kraju, poświęcenie dla ojczyzny. Wychowanie żołnierza - patrioty nadal było jednak wychowaniem stanowym. Do połowy XVIII wieku ideałem człowieka był katolik, miłośnik wolności i patriota.

Po klęsce powstania styczniowego (1863 - 1864) rozpoczęła się w Polsce nowa epoka - pozytywizm (1864). Według pozytywistów, patriotyzm to nie walka zbrojna z zaborcą, lecz praca organiczna, czyli działania na rzecz rozwoju gospodarczego oraz innych dziedzin życia. Pojawiają się hasła „bogaćcie się", "rozumny egoizm”, które sugerują, aby ludzie pomnażali osobisty majątek i tworzyli miejsca pracy dla uboższych - dążenie do dobrobytu, ale nie kosztem interesu ogólnospołecznego. Eksponowanymi wartościami była: praca, pracowitość, udział w życiu społecznym, pomoc ubogim, wyposażenie wychowanków w cechy umożliwiające spełnianie zadań życiowych, użyteczność, optymizm, altruizm, solidaryzm społeczny, cnota, nauka, sztuka, dobrobyt społeczny. Rozwój człowieka miał dokonywać się poprzez życie fizyczne, estetyczne, zawodowe, rodzinne, obywatelskie ${ }^{21}$.

Wraz z powstaniem i rozwojem kapitalizmu, od końca XVIII do XX wie$\mathrm{ku}$, nastąpiło duże zróżnicowanie światopoglądowe, co znacząco wpłynęło na rozwój myśli o wychowaniu. W tym czasie ukształtowały się dwa ruchy społeczno-polityczne: demokratyzm i nacjonalizm.

Demokratyzm wprowadzał stopniowo formalną równość obywateli, nadawał prawa wyborcze, rozdzielił trzy władze: ustawodawczą, sądowniczą i wykonawczą, rozszerzał prawa obywatelskie (wolność słowa, sumienia, stowarzyszeń), przyznawał robotnikom prawa do strajku. Zlikwidowanie klęski bezrobocia i polityka monetarna wytworzyły społeczeństwo konsumpcyjne.

Nacjonalizm, czyli ruch wolnościowy dążący do niezależności narodowej, rozwijał się w państwach znajdujących się pod okupacją obcej władzy. Zaczął wychowywać społeczeństwo w duchu patriotyzmu, nienawiści do

rozumowego. Dzięki odpowiednio silnemu uczuciu, wyostrzonej intuicji i wierze w Boga, możliwe jest połączenie się z Bogiem i naturą.

Mesjanizm - jednostka lub naród przejawiający misję posłannictwa wobec ludzkości, zbawienia świata poprzez ofiarę, cierpienie, śmierć. Człowiek mesjanistyczny dla idei jest w stanie poświęcić własne życie.

${ }^{20}$ https:// pl.wikipedia.org/wiki/Romantyzm\#Elementy_światopoglądu [dostęp: 17.03.2018].

${ }^{21}$ D. Mucha, Poglady pedagogiczne pozytywistów na wychowanie młodego pokolenia, Kultura i Wychowanie, 2012, 3, s. 30-47. 
obcych narodowości (szowinizm, antysemityzm), aż w okresie międzywojennym wytworzył się faszyzm i faszystowskie państwo wychowawcze. Komunizm doprowadził do powstania radzieckiego państwa socjalistycznego, a demokratyzm bronił ustroju kapitalistycznego. Jedynie ruch społecznokatolicki nie miał celów politycznych, lecz dążył do chrystianizacji świata.

Duże zróżnicowanie światopoglądowe i aksjologiczne miało istotny wpływ na wychowanie młodego pokolenia i powstawanie systemów wychowawczych. Współczesne systemy oświatowo-wychowawcze bardzo się skomplikowały: $\mathrm{z}$ jednej strony obejmują wychowanie instytucjonalne, $\mathrm{z}$ drugiej - równoległe i rodzinne. Oczywiście, system wychowania jako zespół idei, celów, zasad i norm postępowania jest kształtowany pod wpływem potrzeb, doświadczeń, wiedzy i przekonań społeczeństwa danego czasu - wytwarza to ideologię pedagogiczną w której współdziałają ze sobą takie czynniki, jak: ideologia, teoria i praktyka wychowawcza.

Obecnie wychowanie jest sprawą międzynarodową, czego dowodem są postulaty wychowawcze UNESCO (United National Educational Scientific and Cultural Organization 1945), w których tkwią określone wartości:

1. Wychowanie dla pokoju („Wojny biorą początek w umysłach ludzi”), w klimacie idei ekumenizmu, religijnego pojednania i irenizmu (gr. eirene pokój, postawa otwartości i życzliwości, przeciwstawianie konserwatyzmowi społecznemu i wyznaniowemu).

2. Kierunkiem współczesnego wychowania jest znajomość wzajemnych dążeń poszczególnych narodów, co ma prowadzić do usuwania występujących pomiędzy nimi różnic, a następnie do usuwania nieufności i podejrzliwości, czyli zasada moralnego wychowania ludzkości w wolności, sprawiedliwości i pokoju.

3. Obalenie nazizmu, głoszącego nienawiść do innych ras, nierówność ludzi, na rzecz poszanowania ludzkich praw i równości. Idea ta wywodzi się z filozofii personalistycznej.

4. Konieczność rozpowszechniania kultury, oświaty oraz troska o ludzkie potrzeby fizyczne i duchowe.

5. Pokój musi opierać się na intelektach i moralnej solidarności ludzi.

Te wychowawcze postulaty określają kierunki działań wychowawczych, których celem jest utrzymanie pokoju na świecie, poszanowanie praw każdego człowieka, zniesienie nierówności i niewoli. Zawarte są tu podstawowe idee składające się na ogólnoświatowy system pedagogiczny, ukazujący właściwą drogę postępowania, który powinien stanowić wzorzec dla realizacji funkcji wychowania wszystkich państw ${ }^{22}$.

${ }^{22}$ www.nauki-spoleczne.info/zadania-edukacyjne-unesco [dostęp: 8.03.2018]. 
Współczesne poglądy postulują „wychowanie humanistyczne”, zawierające takie wartości, jak: współczucie, pomocniczość, opiekuńczość, wspomaganie słabszych, cierpiących, pozbawionych samodzielności radzenia sobie w życiu. Chodzi tu o zdolność rozumienia innych ludzi, ich kultury i sposobu życia - do tego potrzebna jest mądrość, czyli zdolność do rozwiązywania zadań własnych z uwzględnieniem innych osób ${ }^{23}$.

Wychowanie moralne zwraca uwagę nie tylko na poznanie obowiązujących norm i zasad kodeksu moralnego, ale przede wszystkim na ich respektowanie.

W problematyce aksjologiczno-wychowawczej pojęcie wychowania moralnego odnosi się zarówno do filozoficznych koncepcji człowieka, jak i do teorii wartości. Istota tego procesu sprowadza się do wykształcenia umiejętności do nawiązywania relacji do siebie samego, otoczenia, świata przyrody, a w przypadku osób wierzących także relacji do Boga ${ }^{24}$.

W XXI wieku naturalną i uniwersalną teorią człowieka jest personalizm filozoficzny, w tym chrześcijański, dotyczący chrześcijan, czyli osób dobrowolnie przyjmujących zasady moralne zawarte w Dekalogu i Ewangelii.

Choć poglądy na zjawisko pluralizmu wartości w odniesieniu do wychowania są różne, to wydaje się, że u podstaw systemu pedagogicznego powinny znaleźć się wartości personalistyczne, czyli naczelne, zajmujące najważniejsze miejsce w hierarchii wartości - wartości samoistne, stanowiące cel sam w sobie.

\section{Refleksje końcowe}

Przez stulecia jedyną podstawą procesu wychowania była religia, a wartości religijne, w naszej kulturze, zajmowały naczelne miejsce - była to socjalizacja religijna. Obecnie żyjemy w czasach pluralizmu aksjologicznego i światopoglądowego, gdzie występują i przenikają się różne wartości, często sprzeczne, na których budowane są systemy wychowania.

Współcześnie proces wychowania dokonuje się w sytuacji pluralizmu wartości i stanowi zasadę organizacyjną życia społecznego. Podstawową cechą pluralizmu jest uznawanie różnorodności, równouprawnienia, prawnego i moralnego przyzwolenia. Społeczeństwo pluralistyczne oferuje swoim członkom możliwość wyboru w różnych sferach życia. Ludzie sami usiłują określić swoje preferencje życiowe i do nich dostosować normy moralne. Zin-

${ }^{23}$ Z. Kwieciński, Potrzeba ksztatcenia w humanistycznej mądrości, [w:] Edukacja, kultura, teologia, red. I. Werbiński, K. Korzecki, Torun 2003, s. 119.

${ }^{24}$ M. Łobocki, Wychowanie moralne w zarysie, Kraków 2002, s. 204. 
tegrowany system moralno-społeczny i orientacja na wartości uniwersalne, uznawane przez całe społeczeństwo, rozpada się i w związku z tym komplikuje się problem wychowania młodego pokolenia.

Rozbicie jednolitego systemu wartości oraz norm jednostkowych i społecznych powoduje duże konsekwencje wychowawcze. Jakie wartości przekazywać wychowankom i na jakich teoriach pedagogicznych się opierać, aby proces socjalizacji był efektywny?

Współcześnie wychowanie ma pomagać wychowankom w odkrywaniu własnych możliwości, zrozumienia świata, siebie i innych ludzi poprzez rozwój postaw empatycznych, uczuciowości, wrażliwości i nieschematycznego myślenia, a przede wszystkim na przygotowaniu do właściwego oraz odpowiedzialnego wartościowania i życia zgodnego z wybranymi wartościami, które nie kolidują z wartościami innych ludzi.

Pluralizm pedagogiczny przejawiający się w różnych koncepcjach wychowania i systemach wartości jest do zaakceptowania tylko wówczas, kiedy nie neguje wartości ponadczasowych, ogólnoludzkich, autotelicznych, humanistycznych, a jednocześnie uczy dostrzegania innych wartości, analizowania i wyciągania wniosków - narzucanie wzorów czy upodobań jest nieskuteczne.

\section{BIBLIOGRAFIA}

Cybal-Michalska A., Zjawisko globalizacji wspótczesnego świata z perspektywy młodzieży szkót średnich, Studia Edukacyjne, 2008, 7.

Dyczewski L., Miejsce i funkcje wartości w kulturze, [w:] Kultura w kręgu wartości, red. L. Dyczewski, Lublin 2001.

Dziewiecki M., Wychowanie ku wartościom, Wychowawca, 1998, 9.

https://pl.wikipedia.org/wiki/Romantyzm\#Elementy_światopoglądu [dostęp: 17.03.2018].

Kot S., Historia wychowania, t. 1, Warszawa 1994.

Kunowski S., Podstawy wspótczesnej pedagogiki, Warszawa 2004.

Kwieciński Z., Potrzeba kształcenia w humanistycznej madrości, [w:] Edukacja, kultura, teologia, red. I. Werbiński, K. Korzecki, Torun 2003.

Lachowski S., Droga ważniejsza niż cel. Wartości w życiu i biznesie, Warszawa 2012.

Lipiec J., W przestrzeni wartości, Kraków 2001.

Litak S., Historia wychowania, t. 1, wyd. 3, Kraków 2010.

Łobocki M., Wychowanie moralne w zarysie, Kraków 2002.

Łobocki M., Teoria wychowania w zarysie, Kraków 2006.

Mariański J., Między rajem a apokalipsa, [w:] O potrzebie wychowania ku wartościom uniwersalnym, red. M. Czerepaniak-Walczak, M. Dudzikowa, Warszawa 2007.

Maslow A., Motywacja i osobowość, Warszawa 2006.

Mucha D., Poglady pedagogiczne pozytywistów na wychowanie młodego pokolenia, Kultura i Wychowanie, 2012, 3.

Nowak M., Teorie i koncepcje wychowania, Warszawa 2008. 
Olbrycht K., Wychowanie do wartości - SW centrum aksjologicznych dylematów wspótczesnej edukacji, Pedagogika Christiana, 2012, 1.

Olbrycht K., Wychowanie do wartości - w centrum aksjologicznych dylematów wspótczesnej edukacji, Pedagogia Christiana, 2012, 1.

Popielski K., Wartości i ich znaczenie w życiu ludzi, [w:] Człowiek - wartość - sens, red. K. Popielski, Lublin 1996.

Tischner J., Kłoczkowski J.A., Wobec wartości, W Drodze, 2001.

Wołoszyn S., Dzieje wychowania i myśli pedagogicznej w zarysie, Warszawa 1964.

www.nauki-spoleczne.info/zadania-edukacyjne-unesco [dostęp: 8.03.2018]. 